\title{
STRESS AND WORK ABILITY IN OIL INDUSTRY WORKERS
}

\author{
Jozo BREŠIĆ ${ }^{1}$, Bojana KNEŽEVIĆ ${ }^{2}$, Milan MILOŠEVIĆc ${ }^{3}$, Tomislav TOMLJANOVIĆ ${ }^{4}$, \\ Rajna GOLUBOVIĆ ${ }^{3}$, and Jadranka MUSTAJBEGOVIĆ ${ }^{3}$ \\ INA-INDUSTRIJA NAFTE d. d. ${ }^{1}$, Clinical Hospital Centre Zagreb ${ }^{2}$, School of Public Health Andrija \\ Štampar ${ }^{3}$, Gradska ljekarna Zagreb ${ }^{4}$, Zagreb, Croatia \\ Received in January 2007 \\ Accepted in June 2007
}

\begin{abstract}
This cross-sectional study conducted between March and June 2006 examined stress at work and work ability of 180 people with different workplaces within an oil company. Office, laboratory, and oil-field workers were invited to complete the "Occupational Stress Assessment Questionnaire - the Oil Industry Version and Work Ability Index (WAI) Questionnaire". The overall response rate was $69.4 \%$, and the final sample size was 125 workers who completed the questionnaires (57 office, 41 laboratory, 27 oil-field workers). Office, laboratory, and oil-field workers differed significantly with respect to age $(P<0.001)$. The oldest were oil-field workers and the youngest were office workers. The average WAI score for office workers was 44.9, for laboratory workers 43.2 and for field workers 39.7, indicating satisfying work ability. After adjusting for age, the difference in WAI score between the groups of workers was still significant $(P<0.001)$. Over $75 \%$ of all workers believed their job was stressful, but the perception of specific stressors depended on the workplace.
\end{abstract}

KEY WORDS: laboratory workers, office workers, oil-field workers, stressors, work ability index

Stress at work is a specific type of stress whose sources are at the workplace or in the working environment. The concept of stress at work comprises changes consequential to stressors present at the workplace over longer periods of time. Stressful jobs may lead to the so called burnout syndrome which not only increases the risk of getting ill, but also affects private and social life, reduces the sense of self-esteem and the quality of work, as well as safe performance at work (1-5).

Taking into consideration that the number of stressors in the working environment is in continuous rise, stress at work seems to be unavoidable. External stressors are relatively easy to identify, partly or completely eliminate, or at least mitigate. These include unfavourable macro- and micro-climatic conditions, such as high and low temperatures, humidity or dry air, chemical evaporations, noise, and poor ergonomic conditions. Psychosocial stressors are more difficult to discover and define. Stress at work involves the action and interaction of a number of factors, including conflicts between workers and their working environment, genetic factors, culture, tradition, as well as social and economic circumstances in a particular environment (1). There are indications that numerous disorders and diseases are stress-related: musculoskeletal, cardiovascular, and endocrinological diseases, psychic and emotional disorders, a series of psychosomatic diseases, infectious diseases, and finally carcinoma $(3,6,7)$.

Workers employed in oil refining industry are exposed to different health risks, depending on whether they work in oil fields, laboratories, or offices. Workers on oil fields, drilling rigs, and other oil production workplaces are exposed to various chemical hazards, hazardous work materials/substances, gases, vapours, 
fumes, and aerosols, fire, explosives, electricity, falls, and wrecks. Work outdoors and in unfavourable microclimates is affected by atmospheric influences throughout the year, by major physical strain, and high noise levels. It involves a high risk of accidents (cord breaking, explosion) that may lead to wrecking of drilling rigs. Oil is highly inflammable and the use of open flame at wells is prohibited. As gas is released from the well, fragments of rock often fly out under pressure and may cause injuries. Oil from sprinklers can harm unprotected skin. Workers on oil fields are frequently exposed to stressful conditions or to permanent psychic tension. Long-term stay in an isolated area also contributes to the work stress level $(8,9)$.

Laboratory workers are exposed to different stressors than oil-field workers. Gas-processing laboratory workers handle toxic and highly inflammable substances, and use expensive laboratory equipment, which requires special education, high level of attention, and decision-making which may have major financial consequences. Laboratory work dynamics may involve permanent psychic tension (10).

Office workers mostly work in a sitting position and in closed spaces Their work usually involves psychophysical and eye strain and non-physiological positions $(11,12)$. According to the risk assessment, they are exposed to the risk of fire and electric shock (10).

Health and work ability are important factors for occupational safety in oil industry. The aim of this study was to see whether different working conditions and occupational exposure to different hazards in an oil refining company would be associated with different perception of work stressors and work ability.

\section{SUBJECTS AND METHODS}

\section{Study design}

This cross-sectional study was carried out in a Croatian oil company INA-Industrija nafte d.d., Health Care, Safety, and Environmental Protection Department, between March and June 2006. The participation in the study was voluntary. Approval was obtained from the company's ethics committee.

\section{Subjects}

A convenience sample of oil industry workers was selected according to their workplaces and working conditions. At the time of study INA-INDUSTRIJA NAFTE d.d. employed 6890 office workers, 341 laboratory workers, and 2952 oil-field workers. Hundred and eighty workers were invited to participate in this study of whom 57 (31.7\%) were office workers, $41(22.8 \%)$ laboratory workers, and $82(45.5 \%)$ oilfield workers.

\section{Questionnaire}

Workers were invited to complete the Occupational Stress Assessment Questionnaire and Work Ability Index Questionnaire (13). According to literature and pilot studies, the Occupational Stress Assessment Questionnaire $(14,15)$ was created to assess the stress in healthcare workers (16-19). It comprises seven groups of stressors: organisation of work, shift work, financial issues, professional and intellectual demands, interpersonal conflicts at workplace, public criticism, danger and hazards at workplace. The version of Occupational Stress Assessment Questionnaire we used in this study was modified and adapted for oil industry workers.

It contains general information (sex, age, marital status, educational level, workplace, duration of employment, and work hours) and questions about stressors at the workplace. Test subjects were offered 37 stressors to circle and grade using the Likert scale from $1=$ "not stressful at all" to $5=$ "extremely stressful". There where subjects did not experience a particular stressor at workplace, they were instructed to circle 1="not stressful at all" on the Likert scale.

The Work Ability Index (WAI) developed by the Finnish Institute of Occupational Health is a questionnaire-based method assessing perceived work ability. The WAI score was calculated from answers to seven items: current work ability compared with the life time best, work ability in relation to the demands of the job, number of current diseases diagnosed by a physician, estimated work impairment due to diseases, sick leave during the past 12 months, personal prognosis of work ability two years from now, and mental resources. The WAI score ranged from 7 to 49 points. Higher scores indicate better work ability. WAI is considered poor in the range 7-27, moderate in the range 28-36, good in the range of 37-43, and excellent in the range 44-49. Subjects at or below 36 points were classified as having low work ability. Subjects at or above 37 points were classified as having satisfying work ability. 


\section{Statistical analysis}

Smirnov-Kolmogorov test was used to analyze data distribution. Descriptive statistics included the analysis of age, sex, workplace, and reported specific stressors. Kruskal-Wallis test was used to analyze age differences between workplace groups. The analysis of covariance (ANCOVA) was conducted to assess differences in the WAI score between workplace groups. The independent variable was workplace, according to which the subjects were divided in three groups. The dependent variable was the WAI score. Age was used as a covariate to control individual differences. Preliminary checks were conducted to ensure that there was no violation of the assumptions of normality, linearity, homogeneity of variances, and reliable measurement of the covariate.

Differences in the frequency of workers experiencing each potential stressor between the three workplace groups were tested using the chi-square test.

The subjects were divided in two groups: those not stressed by a particular stressor and those stressed. Those whose Likert Scale responses for a specific stressor were 1, 2, or 3 were grouped as not stressed workers, while those whose responses were 4 or 5 were grouped as stressed workers. $P$ values under 0.05 were considered significant. All statistical procedures were performed using the SPSS 13.0 Statistical Package (SPSS Inc, Chicago, IL, USA).

\section{RESULTS}

Response was obtained from 125 subjects (overall response rate was $69.4 \%$ ). Fifty-seven (45.6\%) were office workers, 41 (32.8\%) laboratory workers, and $27(21.6 \%)$ oil-field workers. Office and laboratory workers' response rate was $100 \%$, and that of oilfield workers $33 \%$. Sixty-seven $(53.6 \%)$ subjects who responded were men. Thirty-two office workers $(56.1 \%)$ and 26 laboratory workers (63.4\%) were women, but all 27 oil-field workers were men.

The age median in years (interquartile range) for office workers was 27 (25-28), for laboratory workers 37 (30.5-43), and for oil-field workers 46 (38-52). Differences in age between workplace groups were significant (Kruskal-Wallis chi-square $=71.7, \mathrm{df}=2$, $P<0.001)$ - office workers were the youngest, and oil-field workers were the oldest.

The average WAI score for all workers showed satisfying work ability. The lowest work ability was recorded among the oil-field workers, followed by laboratory workers, while the highest work ability was recorded among the office workers. The average $(\mathrm{WAI} \pm \mathrm{SD})$ score for office workers was excellent: (44.9 \pm 2.9 ), for laboratory workers good: $(43.2 \pm 4.0)$, and for oil-field workers also good: $(39.7 \pm 6.2)$. ANCOVA showed that after adjusting for age, there was a significant difference in the WAI scores between the workplace groups $[\mathrm{F}(3,121)=15.7, \mathrm{P}<0.001$, partial eta square $=0.28$ ].

At least one potential work stressor was reported to be stressful in $51(89.5 \%)$ office workers, 39 $(95.1 \%)$ laboratory workers, and 26 (96.3\%) oil-field workers. The perceived specific stressors differed between workplace groups. Stressful communication with colleagues, conflicts with other staff, public criticism, threats of lawsuits, inadequate expectations of co-workers, and unsolvable problems were more common among office workers than laboratory or oil field workers. As expected, the fear from chemical hazards and fire was more present in the laboratory and oil-field workers than in the office workers. Work overload and overtime, shift work, night shifts, and 24-hour time on duty were more often perceived stressful by the oil-field workers than by the other two groups. Inadequate income and lack of opportunity for professional advancement were equally stressful in all three groups (Table 1).

\section{DISCUSSION}

Due to the nature of their job, office workers more often recognised stressful potential in stressors related to interpersonal relations. Poor communication with colleagues was also the common stressor in the group of laboratory workers. Good communication at work can protect from harmful effects of other stressors, and can contribute to better safety at work $(1,2,4)$.

Oil-field workers had a good communication, and conflicts were not mentioned as stressors, which can be explained by a greater need for teamwork and better task distribution. Unlike with others, stressors perceived by oil-field workers point to more difficult work conditions and stressful working schedule.

Laboratory and oil-field workers reported stressful fear from chemical hazards and fire more often due to real exposure to these hazards and their impact on the safety of workers on these workplaces.

The perception of 23 potential stressors did not differ between the groups of workers. Approximately 
Table 1 Perception of specific stressors as stressful, and differences between workplace groups

\begin{tabular}{|c|c|c|c|c|c|c|}
\hline Stressor & $\begin{array}{c}\text { Office workers } \\
\text { N (\%) }\end{array}$ & $\begin{array}{c}\text { Laboratory } \\
\text { workers } \\
\text { N (\%) }\end{array}$ & $\begin{array}{l}\text { Oil-field workers } \\
\qquad \text { N (\%) }\end{array}$ & Chi-square & $\mathrm{df}$ & $\mathrm{P}^{*}$ \\
\hline Work overload & $12(21.1)$ & $16(39.0)$ & $19(70.4)$ & 19.0 & 2 & 0.000 \\
\hline Poor work organization & $20(25.1)$ & $18(43.9)$ & $11(40.7)$ & 0.8 & 2 & 0.666 \\
\hline Overtime work & $5(8.8)$ & $4(9.8)$ & $8(29.6)$ & 7.6 & 2 & 0.023 \\
\hline Working shifts & $3(5.3)$ & $2(4.9)$ & $14(51.9)$ & 35.9 & 2 & 0.001 \\
\hline Night shifts & $7(12.3)$ & $3(7.3)$ & $15(55.6)$ & 27.6 & 2 & 0.000 \\
\hline Time on duty (24 hours) & $11(19.3)$ & $4(9.8)$ & $11(40.7)$ & 9.6 & 2 & 0.008 \\
\hline Deadlines & $18(31.6)$ & $16(39.0)$ & $12(44.4)$ & 1.43 & 2 & 0.488 \\
\hline Lack of time for work & $18(31.6)$ & $13(31.7)$ & $11(40.7)$ & 0.8 & 2 & 0.675 \\
\hline New technologies & $4(7.0)$ & $7(17.1)$ & $5(18.5)$ & 3.2 & 2 & 0.205 \\
\hline New professional information & $10(17.5)$ & $10(24.4)$ & $4(14.8)$ & 1.1 & 2 & 0.563 \\
\hline $\begin{array}{l}\text { Inadequate continuous } \\
\text { education }\end{array}$ & $20(35.1)$ & $15(36.6)$ & $11(40.7)$ & 0.3 & 2 & 0.881 \\
\hline $\begin{array}{l}\text { Unavailability of professional } \\
\text { literature }\end{array}$ & $14(24.6)$ & $9(22.0)$ & $11(40.7)$ & 3.3 & 2 & 0.195 \\
\hline Poor resources for work & $19(33.3)$ & $16(40.0)$ & $12(44.4)$ & 1.0 & 2 & 0.585 \\
\hline Inadequate working space & $26(45.6)$ & $19(46.3)$ & $7(25.9)$ & 3.5 & 2 & 0.175 \\
\hline Inadequate income & $26(45.6)$ & $26(63.4)$ & $14(51.9)$ & 3.0 & 2 & 0.218 \\
\hline $\begin{array}{l}\text { Poor communication with } \\
\text { superior }\end{array}$ & $15(26.3)$ & $10(24.4)$ & $7(25.9)$ & 0.05 & 2 & 0.976 \\
\hline $\begin{array}{l}\text { Poor communication with } \\
\text { colleagues }\end{array}$ & $15(26.3)$ & $10(24.4)$ & $1(3.7)$ & 6.2 & 2 & 0.046 \\
\hline Bypass for promotion & $30(52.6)$ & $24(58.5)$ & $10(37.0)$ & 3.1 & 2 & 0.213 \\
\hline Excessive paperwork & $11(19.3)$ & $10(24.4)$ & $4(14.8)$ & 1.0 & 2 & 0.617 \\
\hline Lack of co-workers & $18(31.6)$ & $13(31.7)$ & $18(66.7)$ & 10.9 & 2 & 0.004 \\
\hline Unpredictable situations & $13(22.8)$ & $12(29.3)$ & $13(48.1)$ & 5.6 & 2 & 0.061 \\
\hline Conflicts with the superior & $17(29.8)$ & $8(19.5)$ & $2(7.4)$ & 5.6 & 2 & 0.061 \\
\hline Conflicts with colleagues & $13(22.8)$ & $4(9.8)$ & $2(7.4)$ & 4.8 & 2 & 0.092 \\
\hline Conflicts with other staff & $9(15.8)$ & $1(2.4)$ & $0(0.0)$ & 8.8 & 2 & 0.012 \\
\hline Conflicts with other people & $5(8.8)$ & $2(4.9)$ & $0(0.0)$ & 2.7 & 2 & 0.256 \\
\hline Public criticism & $14(24.6)$ & $4(9.8)$ & $1(3.7)$ & 7.6 & 2 & 0.023 \\
\hline Threats of lawsuit & $17(29.8)$ & $5(12.2)$ & $1(3.7)$ & 9.9 & 2 & 0.007 \\
\hline Professional and private life & $14(24.6)$ & $4(9.8)$ & $5(18.5)$ & 3.5 & 2 & 0.175 \\
\hline 24-h responsibility & $10(17.5)$ & $7(17.1)$ & $7(25.9)$ & 1.0 & 2 & 0.604 \\
\hline $\begin{array}{l}\text { Inadequate expectations of } \\
\text { co-workers }\end{array}$ & $12(21.1)$ & $2(4.9)$ & $2(7.4)$ & 6.5 & 2 & 0.039 \\
\hline Misinforming of co-workers & $8(14.0)$ & $3(7.3)$ & $2(7.4)$ & 1.5 & 2 & 0.476 \\
\hline Unsolvable problems & $20(35.1)$ & $5(12.2)$ & $2(7.4)$ & 11.5 & 2 & 0.003 \\
\hline Radiation & $12(21.1)$ & $7(17.1)$ & $8(29.6)$ & 1.5 & 2 & 0.464 \\
\hline Chemical hazards & $13(22.8)$ & $23(56.1)$ & $13(48.1)$ & 12.2 & 2 & 0.002 \\
\hline Fire & $5(8.8)$ & $17(41.5)$ & $15(55.6)$ & 23.3 & 2 & 0.000 \\
\hline Infection & $8(14.0)$ & $7(17.1)$ & $3(11.1)$ & 0.5 & 2 & 0.786 \\
\hline Sharp object & $5(8.8)$ & $6(14.6)$ & $4(14.8)$ & 1.0 & 2 & 0.596 \\
\hline
\end{tabular}

Significance: chi-square test between groups; $\mathrm{df}=$ degrees of freedom 
half the workers in all groups rated inadequate personal income and no opportunities for professional advancement as causes of stress at work. More than a third of all workers perceived poor work organisation, deadlines, insufficient time to perform work, lack of permanent education, poor resources for work, and inadequate working space as causes of stress.

In this study there is a significant age difference among the subjects; the oldest were the oil-field workers and the youngest worked in the office. The concept of work ability presumes a modern concept of human ability for work, emphasizing the need for adjusting work conditions to worker's abilities and capabilities. A worker's psychophysical abilities change with time (13). The average WAI score among oil industry workers above 36 points indicated satisfying work ability. Excellent WAI was obtained from office workers, while the WAI score of laboratory and oil-field workers was good. The difference in WAI between laboratory workers, oil-field workers, and office workers was statistically significant, which might be related to different conditions at work and to the age of workers.

Research of connection between stress at work and mental health of workers in the oil industry shows that occupational stress affects psychological health state $(19,24)$. A research conducted among the oil industry workers in Great Britain showed that conditions at work such as working in shifts, work requirements, and work environment influence different perception of work and work difficulty. Working in shifts can have more negative impact on health than working during daytime hours (20).

Stress at work can reduce safety and increase chances for occupational injury of workers working on oil platforms (21). Onshore workers working on oil platforms more frequently suffer from musculoskeletal illnesses than offshore workers (23). Some studies (22, 23) showed that the work ability of oil industry workers became lower with age, working time, and stress levels. Work ability in women workers was significantly higher than in men.

The limitations of our study are the small number of oil-field workers, age differences between the groups of workers working in different conditions which may influence the WAI score, unequal sex distribution, and the cross-sectional design of the study. For future investigations we propose conducting a longitudinal prospective study with more participants for easier follow-up. As for the health and safety of workers, we propose more effective preventive measures to maintain satisfying work ability.

\section{CONCLUSION}

Most oil company workers in our study, regardless of whether they work in the office, laboratory, or oilfield, believed that they were pronouncedly exposed to stress. Over three quarters of all subjects believed their job was stressful, but the perception of specific stressors depended on the workplace. The average WAI score of all subjects suggested satisfying work ability. Our results call for additional training of workers in communication skills and preventive measures to improve health and safety in the workplace.

\section{REFERENCES}

1. Pavičević L, Bobić J. Stres na radu [Sress at Work; in Croatian]. In: Šarić M, Žuškin E, editors. Medicina rada i okoliša. Zagreb: Medicinska naklada; 2002. p. 530-7.

2. Holland PJ. Psychiatric aspects of occupational medicine. In: McCunney, editor. A Practical Approach to Occupational and Environmental Medicine. Boston: Little, Brown and Company; 1994. p. 265-79.

3. Van Dijk FJH, Swaen GMH. Fatigue at work. Occup Environ Med 2003;60(Suppl.1):1-2.

4. Kragelj LZ, Pahor M, Billban M. Identification of population groups at very high risk for frequent perception of stress in Slovenia. Croat Med J 2005;46:137-46.

5. Bosma H, Stansfeld SA, Marmot MG. Job control, personal characteristics, and heart disease. J Occup Health Psychol 1998;3:402-9.

6. Bosma H, Marmot MG, Hemingway H, Nicholson AC, Brunner E, Stansfeld SA. Low job control and risk of coronary heart disease in Whitehall II (prospective cohort) study. Br Med J 1997;314:558-65.

7. Griffin JM, Fuhrer R, Stansfeld SA, Marmot M. The importance of low control at work and home on depression and anxiety: do these effects vary by gender and social class? Soc Sci Med 2002;54:783-98.

8. Barković D. Industrija nafte, petrokemije i plastike [Oil, petrochemical and plastic industry; In Croatian]. In: Šarić M, Žuškin E, editors. Medicina rada i okoliša. Zagreb: Medicinska naklada; 2002. p. 619-38.

9. INA u zaštiti okoliša, zaštiti zdravlja i sigurnosti. Godišnje izvješće 2002. [INA in environmental protection, health care and safety: 2002 Annual Report; in Croatian]. Zagreb: INA; 2003.

10. Procjena opasnosti radnih mjesta [Evaluation of Workplace Hazard; In Croatian]. Zagreb: INA industrija nafte d.d.; 2003.

11. Korhonen T, Ketola R, Toivonen R, Luukkonen R, Hakkanen M, Viikari-Juntura E. Work related and 
individual predictors for incident neck pain among office employees working with video display units. Occup Environ Med 2003;60:475-82.

12. Occupational Safety and Health Administration (OSHA). Computer Workstation. [displayed 21 May 2007]. Available at http://www.osha.gov/SLTC/etools/ computerworkstations/wkstation_enviro.html

13. Ilmarinen J, Toumi K, Klockars M. Changes in the work ability of active employees over an 11-year period. Scand J Work Environ Health 1997;23(Suppl. 1):4957.

14. Knežević B, Belošević Lj. Stresori na radnom mjestu vojnih liječnika: preliminarno istraživanje [Stress at work among military doctors: a preliminary study, in Croatian]. Acta Med Croat 2006;60:301-7.

15. Elo A-L, Leppänen A, Lindström K, Ropponen T. Occupational Stress Quesstionnaire: User's instruction. Helsinki: Finnish Institute for Occupational Health; 1992.

16. Knežević B, Mustajbegović J, Grubišić Ilić M. Stressors at the physicians' workplace (pilot study). In: Mustajbegović J, Nola Iskra A., Pucarin Cvetković J, editors. 12 $2^{\text {th }}$ Motovun Summer School of Health Promotion. Report. Motovunski glasnik Hrvatske mreže zdravih gradova 2005;(51):35-9.

17. Knežević B, Belošević Lj, Živković Korotaj J, Salacan Jelinčić $M$. Stres na radnom mjestu vojnih liječnika [Stress at work among military doctors, in Croatian] In: Milas Z, editor. Proceedings of the $2^{\text {nd }}$ Croatian Conference of Military Medicine; 20-22 Oct 2005; Zagreb, Croatia. Zadar: Tiskara Zadar; 2005. p. 136.
18. Knežević B, Milošević $M$, Mustajbegović J, Belošević Lj. Stres na radnom mjestu izvanbolničkih i bolničkih liječnika [Stress at work among hospital and nonhospital physicians, in Croatian]. In: Ćubela Adorić V, Penezić Z, Proroković A, Vulić-Prtorić A, editors. Proceedings of the $15^{\text {th }}$ Psychology Days in Zadar; 25-27 May 2006; Zadar, Croatia. Zagreb: Hrvatski liječnički zbor, Hrvatsko društvo za vojnu medicine; 2006. p. 91.

19. Liu J, Wang Z, Wang M, Lan Y, Zhan C, Zhao X. Study on the relationsip between occupational stress and psychological health state among oil workers. Zhonghua Lao Dong Wei Sheng Zhi Ye Bing Za Zhi 2002;20:23-5.

20. Parkers KR. Shiftwork and environment as interactive predictors of work perceptions. J Occup Health Psychol 2003;8:266-81.

21. Chen W, Huang Z, Yu D, Lin Y, Ling Z, Tang J. An exploratory study on occupational stress and workrelated unintentional injury in off-shore oil production. Zhonghua Liu Xing Bing Xue Za Zhi 2002;23:441-4.

22. Liu J, Wang Z, Wang M, Lan Y. Factors of occupational stress on the working ability of petroleum workers. Wei Sheng Yan Jiu 2001;30:263-5.

23. Morken T, Tveito TH, Torp S, Bakke A. Musculoskeletal disorders in the offshore oil industry. Tidsskr Nor Laegeforen 2004;124:2623-6.

24. Miyata M, Tanaka Y, Tsuji S. Occupational stress as the cause of psychosomatic and mental disorders. J UOEH 1997;19:297-305. 


\section{Sažetak}

\section{STRES I RADNA SPOSOBNOST RADNIKA U NAFTNOJ INDUSTRIJI}

Cilj ovog ispitivanja bio je procijeniti doživljaj stresa na radnome mjestu i radnu sposobnost zaposlenih u različitim dijelovima radnog procesa naftne industrije. Presječno istraživanje provedeno je u hrvatskoj naftnoj industriji, u razdoblju od ožujka do lipnja 2006. s uzorkom od 180 prigodno odabranih zaposlenika. Zaposlenici u uredu, laboratoriju za preradu nafte i naftnom pogonu trebali su ispuniti Upitnik o stresu na radu - verzija za naftnu industriju i Upitnik za procjenu indeksa radne sposobnosti (WAI). Ukupni odaziv ispitanika bio je 69,4 \% te je obrađeno 125 ispunjenih upitnika (57 radnika iz ureda, 41 iz laboratorija i 27 iz naftnog pogona). Radnici iz ureda, laboratorija i naftnih pogona značajno su se razlikovali u dobi $(P<0,001)$. Najstariji su bili radnici u naftnim pogonima, dok su najmlađi bili radnici u uredu. Prosječni WAI za uredske zaposlenike bio je 44,9 , za laboratorijske 43,2 , a za zaposlenike u naftnom pogonu 39,7 , što upućuje na zadovoljavajuću radnu sposobnost. Uzevši u obzir utjecaj dobi pri testiranju razlika, utvrđeno je kako se WAI promatranih skupina statistički značajno razlikuju $(P<0,001)$. Više od tri četvrtine svih ispitanika procjenjuje svoj posao kao stresan, no vrste stresora koje doživljavaju razlikuju se ovisno o radnome mjestu.

KLJUČNE RIJEČI: indeks radne sposobnosti, laboratorijski radnici, radnici u naftnim pogonima, stresori, uredski radnici

\section{CORRESPONDING AUTHOR:}

Jozo Brešić, B.Sc.

INA-INDUSTRIJA NAFTE d.d.

Health Care, Safety, and Environmental

Protection Sector

Av. V. Holjevca 10, HR-10002 Zagreb

E-mail:jozo.bresic@ina.hr 